\title{
Effect of Ginkgo biloba on lipid profile in hypertensive patients on Valsartan monotherapy
}

\author{
Luma M Saadallah*, Imad A-J Thanon** \\ *Department of Clinical Pharmacy, College of Pharmacy, ${ }^{\star \star}$ Department of Pharmacology, College of Medicine, University of \\ Mosul, Mosul, Iraq. Correspondence: Imad A-J Thanon. imadpharma@yahoo.com.
}

(Ann Coll Med Mosul 2018; 40 (2): 29-33).

Received: $24^{\text {th }}$ Jun. 2018; Accepted: $1^{\text {st }}$ Nov. 2018.

\section{ABSTRACT}

Aim: The study was conducted to evaluate the effects of Ginkgo biloba as an add on therapy to Valsartan monotherapy in hypertensive patients on lipid profile.

Patients and methods: The study was done in private clinics in Mosul City, during a period of sixth months from 15 October 2017 to 15 April 2018. The total number of patients enrolled in the study was 50 hypertensive patients using Valsartan monotherapy of both sexes. The patients were administered Ginkgo biloba $80 \mathrm{mg}$ twice daily and followed for 2 months duration. Their lipid profile was determined at baseline level and after 2 months from administration of Ginkgo biloba.

Results: Treatment with Ginkgo biloba showed a significant reduction in serum total cholesterol and triglycerides, while LDL, VLDL, HDL, and Al showed no significant changes.

Conclusion: This study revealed that Ginkgo biloba could be regarded as a natural and relatively safe drug in reducing total cholesterol and triglycerides in hypertensive patients.

Keywords: Hypertensive patients, Valsartan monotherapy, Ginkgo biloba, lipid profile.

$$
\begin{aligned}
& \text { تاثير عقار الجنكوبايلوبا على مستوى الدهون بالام لمرضى فرط }
\end{aligned}
$$

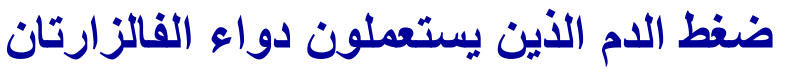

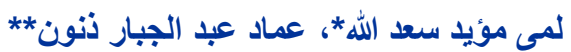

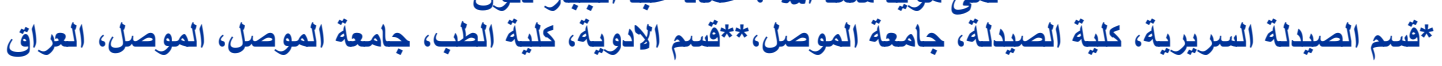

الهدف من الاراسة: دراسة تاثثير الجنكوبايلوبا على مستوى الدهنيات بالدم عندما يستعمل كدواء إضافي الي دواء الفالزارتان

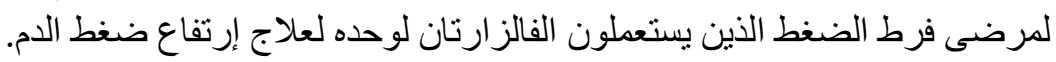

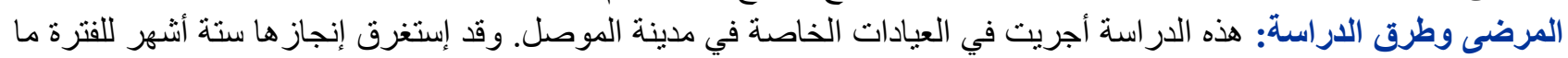

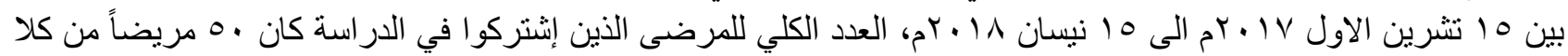

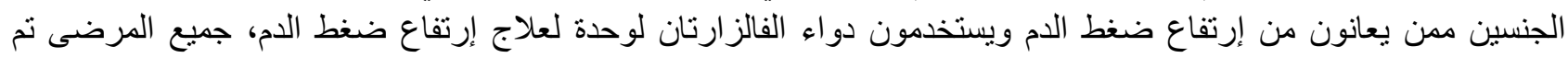

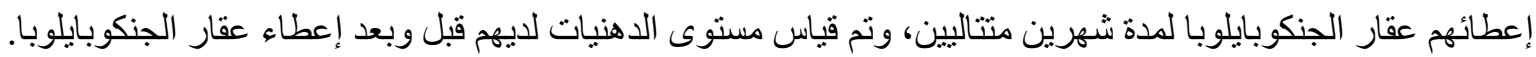

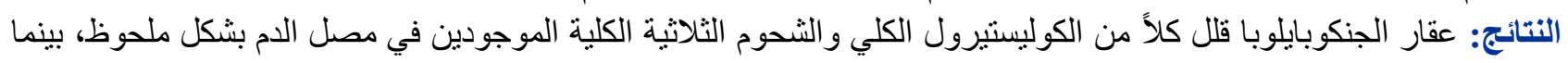

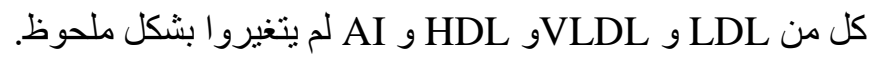
الاستنتاج: هذه الدراسة أكدت أن عقار الجنكوبايلوبا من الممكن أن يكون عامل طبيعي و آمن نسبيا لتخفيض مستوى الكوليسترول

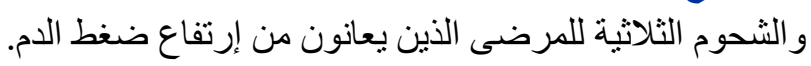

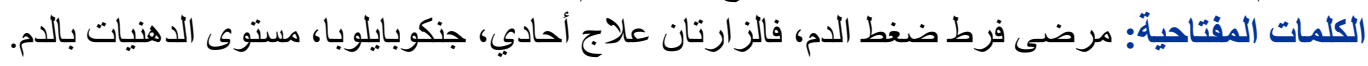




\section{INTRODUCTION}

inkgo biloba is one of the most ancient's world living tree species ${ }^{1}$. The extract of Ginkgo biloba leaves has a long history of uses in medicine $^{2}$, it is effective for treatment of wide ranges of diseases like Alzheimer's, dementia, traumatic brain injury, stroke, cerebral insufficiency, tinnitus, sexual dysfunction, and macular degeneration ${ }^{3}$.

Ginkgo biloba is relatively safe drug and few adverse effects are associated with it ${ }^{4}$. Occasionally it may cause stomach upset, headache, dizziness, constipation, palpitation, allergic skin reactions, in addition it might increase the risk of bruising and bleeding ${ }^{5}$.

Hyperlipidemia is defined as elevated blood lipids levels, which include cholesterol and triglycerides $^{6}$. It has an important role in the development and progression of atherosclerosis and coronary heart diseases ${ }^{7}$. Reducing lipid concentration by drugs is highly effective in reducing the risk of cardiovascular disease ${ }^{8}$. There are various synthetic lipid-lowering agents employed in current treatment of hyperlipidemia, including statins, fibrates, niacin, and ezetimibe ${ }^{9}$, in spite of their beneficial effects, they are associated with some side effects such as rhabdomyolysis and myopathy. Therefore, there is an increased need for new lipid-lowering agents with high therapeutic value and minimum side effects ${ }^{10}$.

The aim of present study is to investigate the effect of ginkgo biloba on lipid profile in hypertensive patients taking valsartan as monotherapy for hypertension.

\section{PATIENTS AND METHOD}

Descriptive, a prospective case series study design was used in this study which was conducted in private clinics in Mosul City. Out of 58 patients with hypertension only 50 patients completed this 2 months study in the period from October 2017 to April 2018. Eight patients refused to complete the study due to different causes (three of them because of side effects especially gastric upset and palpitations, while the other five found it is difficult to adhere with Ginkgo biloba twice daily dosage regimens).

The ethical requirement for the study was obtained from the college of pharmacy in Mosul
University and a consent form was obtained from each patient. Patients having hypertension for at least one year, and on valsartan monotherapy (Valsartan was chosen because it is one of the most commonly prescribed antihypertensive drugs) for at least 6 months in a dose range of $80 \mathrm{mg}$ to $160 \mathrm{mg}$ daily were included in this study. Patients who have diabetes mellitus, epilepsy, renal or liver diseases, pregnant or breast feeding mothers, or patients who used any drug that might affect the coagulation system or used drugs other than Valsartan for hypertension were excluded from the study.

All patients received Ginkgo biloba $80 \mathrm{mg}$ capsule (provided by Adrein Gagnon, Canada) twice daily for 2 months. The patients continued on their initial antihypertensive drug (Valsartan).

The analysis of biochemical parameters were done at Al-Ehsan laboratories in Mosul city. At the start $5 \mathrm{ml}$ of venous blood sample was taken from each patient after 13 hours from fasting before administration of Ginkgo biloba, the serum was obtained by centrifugation and kept frozen at -20 $\mathrm{C}^{\circ}$ to be used for the spectrophotometric measurement of total cholesterol ${ }^{11,12}$, triglycerides 13,12, and HDL-c ${ }^{14}$.

VLDL was calculated by the equation ${ }^{15}$ :

VLDL=Total triglycerides/5.

Serum LDL concentration was calculated by the Friedwald equation ${ }^{15}$ :

LDL $(\mathrm{mg} / \mathrm{dl})=$ total cholesterol-HDL cholesteroltriglycerides $/ 5$.

Atherogenic index (Al) was calculated by the equation $^{16}$ :

$\mathrm{Al}=$ Total cholesterol/HDL.

Anthropometric measurement were recorded including height $(\mathrm{cm})$ and weight $(\mathrm{kg})$ and body mass index (BMI) was calculated as:

BMI $\left(\mathrm{kg} / \mathrm{m}^{2}\right)=$ Weight $(\mathrm{kg}) /$ Height $\left(\mathrm{m}^{2}\right)^{17}$.

After 2 months of administration of Ginkgo biloba another blood sample was taken from each patient and, the above biochemical measurements and calculations were repeated again.

\section{Statistical Analysis}

Paired student t-test was used to compare results before and after Ginkgo biloba treatment. 


\section{RESULTS}

\section{Patients characteristics':}

Fifty patients (23 male 46\%) and (27 female 54\%) were included in the study, as shown in Table 1.

Table 1. Baseline characteristics of the study sample $(n=50)$.

\begin{tabular}{lcccc}
\hline & Mean & SD & Minimum & Maximum \\
\hline Age (years) & 48.20 & 10.73 & 24.0 & 72.0 \\
$\begin{array}{l}\text { Height } \\
\text { (Cm) }\end{array}$ & 165.31 & 8.79 & 150.0 & 187.0 \\
Weight $(\mathrm{kg})$ & 78.20 & 12.48 & 50.0 & 110.0 \\
\hline BMI $\left(\mathrm{kg} / \mathrm{m}^{2}\right)$ & 28.88 & 5.87 & 19.03 & 44.44 \\
\hline
\end{tabular}

2. Changes in serum lipid profile after 2 months of treatment with Ginkgo biloba:

The mean values of serum lipids before and after treatment with Ginkgo biloba along with their percentage of changes are shown in Table 2.

Table 2. Rate of changes in serum lipid profile parameters after 2 months of "ginkgo biloba usage" in the study sample (n $=50)$.

\begin{tabular}{lccccc}
\hline & $\begin{array}{c}\text { Base line } \\
(\text { Mean } \pm \text { SD) }\end{array}$ & $\begin{array}{c}\text { After 2 months } \\
(\text { Mean } \pm \text { SD) }\end{array}$ & $\begin{array}{c}\text { Changes } \\
(\text { Mean } \pm \text { SD) }\end{array}$ & $\begin{array}{c}\text { Change } \\
\text { Rate }(\%)\end{array}$ & p-value* \\
\hline S. cholesterol $(\mathrm{mg} / \mathrm{dl})$ & $187.20 \pm 49.88$ & $173.46 \pm 39.49$ & $-13.74 \pm 36.32$ & 7.34 & 0.010 \\
\hline HDL $(\mathrm{mg} / \mathrm{dl})$ & $43.72 \pm 10.00$ & $42.18 \pm 8.55$ & $-1.54 \pm 10.17$ & 3.52 & 0.290 \\
LDL $(\mathrm{mg} / \mathrm{dl})$ & $116.48 \pm 44.36$ & $107.88 \pm 34.06$ & $-8.60 \pm 35.41$ & 7.38 & 0.092 \\
VLDL $(\mathrm{mg} / \mathrm{dl})$ & $26.94 \pm 15.76$ & $23.78 \pm 13.95$ & $-3.16 \pm 10.00$ & 11.73 & 0.030 \\
TG $(\mathrm{mg} / \mathrm{dl})$ & $135.40 \pm 78.60$ & $119.10 \pm 69.90$ & $-16.28 \pm 49.78$ & 12.02 & 0.025 \\
\hline Atherogenic index & $4.38 \pm 1.33$ & $4.28 \pm 1.16$ & $-0.10 \pm 1.22$ & 2.28 & 0.574 \\
\hline
\end{tabular}

${ }^{*}$ Paired Student T-test of two means was used, $p$-value $<0.05$ was significant

\section{DISCUSSION}

Hypertension and hyperlipidemia are considered to be important risk factors for cardiovascular diseases. ${ }^{18}$ Several epidemiological studies have reported that gradual increases in blood pressure or prevalence of hypertension are associated with hyperlipidemia. $^{19}$

Ginkgo biloba extract (GBE) is widely used as a dietary supplement for the treatment of cardiovascular disorders particularly ischemic cardiac syndrome ${ }^{20}$. The mixture of biologically active ingredients present in GBE has a number of physiological effects, including antioxidant ${ }^{21}$, vasodilation $^{22}$ and inhibition of platelet aggregation ${ }^{23}$. In addition to these actions, GBE reduces the formation and size of atherosclerotic plaques in high-risk cardiovascular patients, minimizes lipid peroxidation, and decreases the level of lipoprotein $(a)^{24}$. These observations reveal the modulating effect of GBE on cholesterol metabolism. In this study the use of Ginkgo biloba resulted in significant reduction in cholesterol and triglycerides levels, non-significant reduction in LDL-cholesterol. The rate of improvement for total cholesterol, triglycerides and LDL were $7.34 \%, 12.02 \%$, and $7.38 \%$ respectively. However, there is a slight reduction in HDL-chlolesterol which is not significant. The level of VLDL which is proportional to triglycerides was also reduced significantly. Atherogenic index was reduced although the reduction was not significant since it is affected by both cholesterol and HDL. The effect of Ginkgo biloba on lipid metabolism was studied more in animals than in human.

In a study done by Yao et $a^{25}$ in rats, Ginkgo biloba was found to lower circulating free cholesterol and inhibit production of brain $\beta$ amyloid precursor protein and amyloid $\beta$-peptide. These findings indicate that free circulating and intracellular cholesterol levels affect the processing of $\beta$-amyloid precursor protein and amyloidogenesis, and both of them were reduced by Ginkgo biloba. In another study done on rats also, Dubey et $a f^{26}$ reported that treatment with 
GBE produced a significant reduction in serum cholesterol, no effect on triglyceride which is in contrast with our results, and almost no effect on HDL-c which is in agreement with our findings.

Studies have referred that GB had an effect on the absorption of triglyceride and cholesterol, metabolism of cholesterol and this might explain the lipid lowering effects of ginkgo biloba ${ }^{27-29}$.

Pancreatic lipase (triacylglycerol acyl hydrolase, $\mathrm{PL}$ ), is an enzyme secreted by pancreas and catalyzed the hydrolysis of triacylglycerides in the gastrointestinal tract, is the key enzyme for lipid absorption $^{30}$. Bustanji et $a l^{27}$ proved that the trilactone terpenes (ginkgolides A, B, and bilobalide) which are important bioactive constituents in G. biloba leaves extract ${ }^{31}$, are considered as potential PL inhibiter ${ }^{27}$. This might explain the action of ginkgo biloba on triglyceride.

The hydrolysis of cholesterol esters in the lumen of the small intestine is catalyzed by pancreatic cholesterol esterase, which liberates free cholesterol $^{32}$. Adisakwattana et $a f^{28}$ reported that polyphenols rich plants like Ginkgo biloba inhibited the intestinal digestion and absorption of dietary lipids by inhibition of pancreatic cholesterol esterase activity.

In another study by Xie et $a l^{29}$ studied the enzyme activity, cholesterol flux, and changes in gene expression levels in cultured hepatocytes treated with Ginkgo biloba or Lovastatin. They found that GB decreased the total cholesterol content in cultured hepatocyte, inhibited the activity of 3-Hydroxymethylglutaryl-CoA reductase, which is the rate limiting step in endogenous cholesterol biosynthesis. In addition Ginkgo biloba decreased cholesterol influx, and induced significant increases in the expression of cholesterogenic genes and genes involved in cholesterol metabolism.

In conclusion: Ginkgo biloba has a natural and relatively safe effects in reducing total cholesterol and triglycerides levels in hypertensive patients when added to other antihypertensive drugs.

\section{REFERENCES}

1.Isah T. Rethinking Ginkgo biloba L: Medicinal uses and conservation. Pharmacogn Rev 2015; 9(18): 140148.

2.Ramassamy C, Longpre F, Christen Y. Ginkgo biloba extract (EGb 761) in Alzheimer disease: is there any evidence?. Curr Alzheimer Res 2007; 4(3): 253-262.
3.Diamond BJ, Shiflett SC, Feiwel N, Matheis RJ, Noskin O, Richards JA, et al. Ginkgo biloba extract: mechanisms and clinical indications. Arch Phys Med Rehabil 2000; 81(5): 668-678.

4.Weinmann S, Roll S, Scharzbach C, Vauth C, Willich SN. Effects of Ginkgo biloba in dementia: Systematic review and meta-analysis. BMC Geriatr: 2010; 10-14.

5.Roland PD, Nergård CS. Ginkgo biloba--effect, adverse events and drug interaction. Tidsskir Nor Laegeforen 2012; 132(8):956-959.

6. Nelson $\mathrm{RH}$. Hyperlipidemia as an a risk factor for cardiovascular disease. Prime care 2013; 40(1): 195211.

7.Abdalamir M, Goyfman M, Chaus A, Dabbous F, Tamura L, Sandfort $\mathrm{F}$ et al. The correlation of dyslipidemia with the extent of coronary artery disease in the multiethnic study of atherosclerosis. J Lipids 2018; ID 5607349.

8.Last AR, Ference JD, Menzel ER. Hyperlipidemia: drugs for cardiovascular risk reduction in adults. Amer Fam Phys 2017; 95(2): 78-87.

9.Barter PJ, Rye KA, Touyz RM. New Era of lipidlowering drugs. Pharmacol Rev 2016; 68(2): 458-475.

10.Saghir SAM, Revadigar V, Murugaiyah V. Natural lipid-lowering agents and their effects: An update. Eur Food Res Technol 2014; 238(5):705-725 .

11.Richmond W. Preparation and properties of cholesterol oxidase from Nocardia SP and its application to the enzymatic assay of total cholesterol in serum. Clin Chem.1973; 19(12): 1350-1356.

12.Virdi NK, Worthington DJ. Cholesterol and triglyceride stability in whole blood. Ann Clin Biochem .1989; 26: 197-198.

13.Fossati $P$, Prencipe $L$ Serum triglycerides determined Calorimetrically with an enzyme that produces hydrogen peroxide._Clin Chem1982; 28(10):2077-2080.

14.Lopes-Virella MF, Stone F, Ellis S, Coiweil JA. Cholesterol Determination in High-Density Lipoproteins Separated by Three Different Methods. Clin Chem 1977; 23(5): 882- 884.

15.Friedwald WT, Levy R, Frederickson DS. Estimation of low density lipoprotein in plasma without use of the preoperative ultracentrifuge. Clin Chem1972; 18(6): 499502.

16.Kinosian B, Glick H, Garland G. Cholesterol and coronary heart disease: predicting risks by levels and ratios. Ann Intern Med 1994; 121(9):641-647.

17.Chan DC, Watts GF, Barrett PH, Burke VS. Waist circumference, waist-to-hip ratio and body mass index as predictors of adipose tissue compartments in men. Q $\mathrm{J}$ Med 2003; 96(6):441-447.

18. Kario K, Saito I, Kushiro T, Teramukai S, Ishikawa $Y$, Mori $Y$, et al. Home blood pressure and cardiovascular outcomes in patients during antihypertensive therapy: primary results of HONEST, a large-scale prospective, real-world observational study. Hypertens 2014; 64(5): 989-996.

19.Freiberg JJ, Tybjaerg Hansen A, Jensen JS, Nordestgaard BG. Nonfasting triglycerides and risk of ischemic stroke in the general population. JAMA 2008; 300(12): 2142-2152.

20.Mahady GB. Ginkgo biloba for the prevention and treatment of Cardiovascular disease: a review of the literature. J Cardiovasc Nurs 2002; 16(4): 21-32. 
21.Aziz TA, Hussain SA, Mahwi TO, Ahmed ZA, Rahman HS, Rasedee A. The efficacy and safety of Ginkgo biloba extract as an adjuvant in type 2 diabetes mellitus patients ineffectively managed with metformin: a double-blind, randomized, placebo-controlled trial. Drug Des Devel Ther 2018;12:735-742.

22.Bent S, Goldberg H, Padula A, Avins AL. Spontaneous bleeding associated with ginkgo biloba: a case report and systematic review of the literature. $J$ Gen Intern Med 2005; 20(7): 657-661.

23. Cho HJ, Nam KS. Inhibitory effect of ginkgolide B on platelet Aggregation in a CAMP- and cGMP-dependent manner by activated MMP-9. J Biochem Mol Biol 2007; 40(5): 678-683.

24.Rodriguez M, Ringstad L, Schafer $P$, Just $S$, Hofer $\mathrm{HW}$, Malmsten $M$, et al. Reduction of atherosclerotic nanoplaque formation and size by Ginkgo biloba (EGb $761)$ in cardiovascular high-risk patients. Atherosclerosis 2007; 192(2): 438-444.

25. Yao ZX, Han Z, Drieu K, Papadopoulos V. Ginkgo biloba extract (Egb761) inhibits beta-amyloid production by lowering free cholesterol Levels. J Nutr Biochem 2004; 15(12): 749-756.

26.Dubey AK, Devi A, Kutty G, Shankan RP. Hypolipidemic activity of Ginkgobiloba extract, EGb 761 in hypercholesterolemic Wistar rats. Iranian J Pharmacol Ther 2005; 4(1): 9-12.
27.Bustanji Y, Al-Masri IM, Mohammad M, Hudaib M, Tawaha $\mathrm{K}$, Tarazi $\mathrm{H}$, et al. Pancreatic lipase inhibition activity of trilactone terpenes of Ginkgo biloba. J Enzyme Inhib Med Chem 2011; 26(4):453-459.

28.Adisakwattana $S$, Intrawangso J, Hemrid A, Chanathong B, Mkynen K. Extracts of edible plants inhibit pancreatic lipase, cholesterol esterase and cholesterol micellization, and bind bile acids: edible plant extracts for treatment of hyperlipidaemia. Food Technol Biotechnol 2012; 50 (1): 11-16

29.Xie ZQ, Liang G, Zhang LU, Wang Q, Qu Y, Gao Y, et al. Molecular mechanisms underlying the cholesterollowering effect of Ginkgo biloba extract in hepatocytes: a comparative study with lovastatin. Acta Pharmacol Sin 2009; 30(9): 1262-1275.

30. Iqbal J, Hussain MM. Intestinal lipid absorption. Am J Physiol Endocrinol Metab 2009; 296(6): 1183-1194.

31.Zhang $Y$, Liu P, Kong Q, Xing S, Liu X, Sun L. The contents of terpene trilactone and flavonoid in leaves of seedlings from ancient female ginkgo trees in China. HPJ 2017; 3(4): 165-171.

32. Brimo $A H$, Nayal $R$. In vitro screening of the pancreatic cholesterol esterase inhibitory activity of some medicinal plants grown in Syria. IJPPR 2016; 8(8): $1432-1436$ 